\title{
Implementation of the Romanian Mining Strategy 2017-2035, with special regard to pit coal: failure or abandonment?
}

\author{
Liliana Roman $^{1}$, and Mircea Georgescu ${ }^{1 *}$ \\ ${ }^{1}$ University of Petroșani, Environmental Engineering and Geology Department, str. Universității \\ no.20, Petroşani, Romania
}

\begin{abstract}
Jiu Valley is currently the only national mining basin capable of producing pit coal. Romania has undergone an extensive industrial restructuring in the last 30 years, including mining, which has led to job losses, generated economic-social and environmental effects that have severely affected the quality of life of the inhabitants of mining communities. As a consequence, the Mining Strategy of Romania 2017 2035 was elaborated. The paper analyses the objectives, measures and actions provided in the strategy related to the exploitation of pit coal, putting, face to face, the true state of the mines and the inhabitants of Jiu Valley. 4 years after the elaboration of the Strategy, it is clear that it has not yet come to life: mines are still being closed, there is no clear vision for the sustainable development of mining communities, the mine closure process, the greening of post-closure areas is difficult or not at all, research (e.g. capture of methane from coal), development and innovation are not stimulated, the operation of coal-fired power plants is endangered, with major implications on the supply of inhabitants with heating and of domestic hot water - resulting in major discomfort for locals.
\end{abstract}

\section{Introduction}

As a result of changes and pressures to modernize its industrial sectors, the government has closely analysed the role of mining in the Romanian economy and the long-term contribution it can make to the sustainable development process and through the Ministry of Economy, Trade and Business Relations developed the Romanian Mining Strategy 2017 - 2035 [1], thus creating the opportunity to substantiate a national development strategy, starting from the knowledge and capitalization of the potential of mineral resources and taking into account the socio-economic dimension and environmental protection.

The strategy proposes to reconsider the position and the way of involvement of the state and the communities in the mining field, by gradually relinquishing the attributions of economic operator and administrator, in favour of emphasizing the regulatory role and promoting policies for developing and stimulating a viable system. which, the private

\footnotetext{
* Corresponding author: mirgeorgescu@gmail.com
} 
entities to have mainly the right of exploitation, operation and administration of the mineral resources and to ensure the financing and the management of the mining activities.

In the European context, the European Union (of which Romania has been a part since 2007) has developed a strategic plan - Strategic Implementation Plan for the European Innovation Partnership on Raw Materials (EIP), as well as the Raw Materials Initiative (RMI), where the field of resources minerals is a priority area. It is based on three pillars (guaranteeing access to raw materials, determining the conditions for a sustainable supply of raw materials from European sources, boosting resource efficiency and promoting recycling in order to reduce raw material consumption and reduce dependence on imports). Actions have been proposed to define essential raw materials, provide legal measures for access to and sustainable management of raw materials, expand the knowledge base at EU level, focus research on innovative technologies for exploration, exploitation, recycling, identification of substitution and efficiency materials [9], [10].

In this paper we will refer only to the Strategy related to pit coal, as a mineral resource for the Romanian energy sector.

Currently, Jiu Valley mining basin remains the only national mining basin capable of producing pit coal, with conceded geological reserves in the perimeter of about 300 million tons, of which exploitable (for which there is a license) 50 million tons.

\section{SWOT analysis of mining in Jiu Valley}

In the Strategy of the mining industry for the period 2017-2035, a SWOT analysis is performed regarding the exploitation of pit coal in Romania. Considering that currently the only exploitable pit coal deposit in our country is the one in the Jiu Valley mining basin, it is implicit that this analysis refers to the mining in this area (table 1).

Table 1. SWOT analysis of mining in Jiu Valley [1].

\begin{tabular}{|c|c|}
\hline \multirow{13}{*}{ 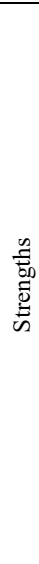 } & $\begin{array}{l}\text { With the current structure of main opening works, exploitation can be ensured at a rate of } 3 \text { - } \\
3.5 \text { million tons /year for over } 30 \text { years. }\end{array}$ \\
\hline & There are qualified and traditional staff trained over 160 years \\
\hline & Concentration of mining operations in relatively small area (approx. $47 \mathrm{~km}^{2}$ ) \\
\hline & Exploitation takes place underground and is insignificantly influenced by climate change \\
\hline & Activity in line with environmental requirements (ISO 14000 and 9001 certified \\
\hline & Minimum environmental impact reduced \\
\hline & $\begin{array}{l}\text { Even if at national level the energy intake of pit coal is small- approx. } 5.7 \% \text { of electricity } \\
\text { production, it can make a significant contribution to national energy security in crisis situations } \\
\text { of other resources }\end{array}$ \\
\hline & $\begin{array}{l}\text { Short distance from the current beneficiaries of pit coal, one of the big beneficiaries being right } \\
\text { in the centre of the mining basin }\end{array}$ \\
\hline & Adequate infrastructure for both the actual extraction and transport to the beneficiaries by rail \\
\hline & $\begin{array}{l}\text { There is a request from the two traditional beneficiaries, for } 10 \text { years at the Paroșeni Thermal } \\
\text { Power Plant and approx. } 3 \text { years at Mintia Thermal Power Plant }\end{array}$ \\
\hline & $\begin{array}{l}\text { The use by the beneficiaries of coal burning processes compatible with the parameters of the } \\
\text { products made with the current exploitation and preparation technologies }\end{array}$ \\
\hline & Owned preparation plants can produce products with an increased energy content \\
\hline & The company holds the Operating License until 2024 \\
\hline \multirow{6}{*}{ 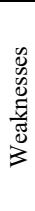 } & $\begin{array}{l}\text { Elimination of state aid (subsidies and transfers for social protection) from } 2011 \text { and lack of } \\
\text { prospect of identifying other sources of aid }\end{array}$ \\
\hline & Large number of mining units with unsatisfactory activity and no prospects \\
\hline & High production cost \\
\hline & Historical debts that burden the company's budget \\
\hline & Losses due to operation each year \\
\hline & Low labor productivity \\
\hline
\end{tabular}




\begin{tabular}{|c|c|}
\hline & Low energy power of the products made \\
\hline & Insufficient modernization and refurbishment of technological processes \\
\hline & Physical work is predominant in the technological process \\
\hline & $\begin{array}{l}\text { The coal deposit has a high content of explosive gases-methane and sulfur being prone to self- } \\
\text { ignition, and the underground atmosphere to ignition or explosion }\end{array}$ \\
\hline & Very high living expenses (lack of refurbishment programs) \\
\hline & $\begin{array}{l}\text { Vulnerability of coal mining to the characteristic and geo-mining conditions (deep mining } \\
\text { depth, tectonics, stratigraphy, variability) }\end{array}$ \\
\hline & $\begin{array}{l}\text { Disinterest in carrying out modernization / refurbishment investigations (from private partners } \\
\text { and the Romanian state }\end{array}$ \\
\hline & $\begin{array}{l}\text { Poor prospects for the inclusion of coal extraction in a complex energy structure in the near } \\
\text { future }\end{array}$ \\
\hline & Lack of a strategy in the coal mining industry \\
\hline & Most mining equipment is morally and / or physically worn out \\
\hline & $\begin{array}{l}\text { The use of coal poses serious and costly environmental problems for beneficiaries (thermal } \\
\text { power plants) }\end{array}$ \\
\hline & $\begin{array}{l}\text { European Union policies are aimed at reducing this energy resource to the medium term due to } \\
\text { the negative impact on the environment }\end{array}$ \\
\hline & $\begin{array}{l}\text { A new comprehensive restructuring and reorganization program comprising: separation of } \\
\text { viable and non-viable mines; the inclusion of viable mines in a new form of organization (CE } \\
\text { Hunedoara); following the steps provided by the legislation in force for the closure of non- } \\
\text { viable mines; reducing the staff to the level necessary for the new organizational structures; } \\
\text { reconsideration of facilities granted to employees and pensioners in the new context of } \\
\text { reorganization of mining activity. }\end{array}$ \\
\hline$\stackrel{\mathscr{E}}{:}$ & $\begin{array}{l}\text { Elaboration and implementation of a viable Social Plan for the Jiu Valley in order to counteract } \\
\text { the effects of mining restructuring }\end{array}$ \\
\hline 吾 & $\begin{array}{l}\text { Encourage, through the European Union's energy strategy, the preservation of access to } \\
\text { indigenous reserves of primary energy resources, in order to ensure national energy security }\end{array}$ \\
\hline & $\begin{array}{l}\text { Maintaining an adequate mining infrastructure to expand the mining operation so as to ensure } \\
\text { the continuity of coal production over a long period of time }\end{array}$ \\
\hline & $\begin{array}{l}\text { Implementation of studies and refurbishment projects in order to develop new production } \\
\text { capacities }\end{array}$ \\
\hline & Investigate the possibilities of capturing methane emissions from the deposits in operation \\
\hline & $\begin{array}{l}\text { Improving the quality of coal sold, with small investments in upgrading the sorting from each } \\
\text { mining operation }\end{array}$ \\
\hline & Long-term insolvency \\
\hline & pliers of materials and services at risk of cessation of activity \\
\hline & or bankruptcy is imminent \\
\hline & close all mines and especially non-viable ones \\
\hline & ocial movements (trade union and non-union) \\
\hline & Inability to insure salary payments \\
\hline 岂 & Imposing a lower delivery price than current one (correlated to the offer on foreign market) \\
\hline$\vec{E}$ & Loss of beneficiaries or reduction of coal demand for them \\
\hline & Social vulnerability due to the poverty of the area \\
\hline & $\begin{array}{l}\text { The probability that the most important coal consumer in Romania - the Mintia thermal power } \\
\text { plant - will replace Jiu Valley coal with imported coal or switch to the use of natural gas as fuel }\end{array}$ \\
\hline & $\begin{array}{l}\text { High sensitivity to the onset of labor disputes with a large masses of workers concentration, in a } \\
\text { short time, due to a volatile social climate in a poor area, deprived of a viable alternative to } \\
\text { mining. }\end{array}$ \\
\hline
\end{tabular}




\section{Evaluation of the mines in Jiu Valley according to the closure criteria}

Jiu Valley is the only mining basin in Romania where a pit coal mine is currently exploited, which has important balance reserves, which can ensure the requirements of the beneficiaries (CET Paroșeni and Mintia-Deva), for a period of several decades.

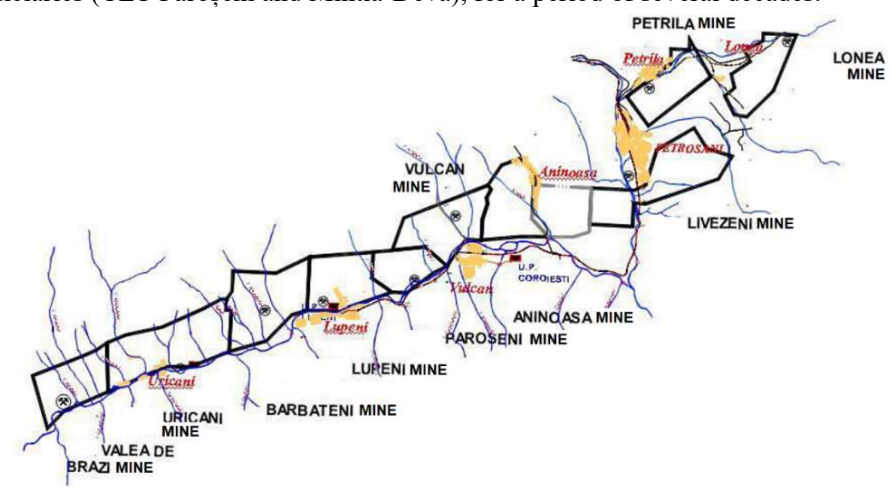

Fig. 1. Mining perimeters in Jiu Valley mining basin [2].

The mines from Jiu Valley (fig.1), with traditional activity, in coal mining have the most qualified personnel and an adequate infrastructure, both for the actual extraction and for the transport to the beneficiaries.

At the same time, however, the complicated tectonics of the deposit make this deposit one of the most complex coal deposits in the world and very difficult to exploit through the methods and technologies widely used worldwide. Therefore, the mining sector of the exploitation of coal deposits in Romania, i.e. the mining activities in the mining basin of Jiu Valley, are in a stalemate that can be overcome, not only by technical-organizational measures but also by responsible political decisions.

After 1989, when the created situation imposed the support of the mining sector by the state with a great budgetary effort, the non-stop decline of mining in Jiu Valley begins.

Several key benchmarks can be highlighted in its decline, caused in particular by the so-called restructuring programs (especially those from 1997 to 2000): mass redundancies; high compensatory payments for redundant staff; dramatic increase in production costs; the drastic decrease of investments by approx. 20 times the value of those before 1989. All this led to a decrease in the production extracted (by $41 \%$ ), the number of employees (by $60 \%$ ), the fluctuation of production costs and, in particular, the total neglect of refurbishment and modernization of all technological processes in the underground and on the surface of a mine.

Thus, after a century of efficiency and half a century of investments materialized in an extensive development, which led to the formation of a first-class mining basin, today we are witnessing, after three decades, a sad end of a mining characterized by inefficiency, rapidly declining production, risks and uncertainties for those still working underground.

After 1990, it is difficult to talk about investments in the mining of Jiu Valley in the absence of a future energy strategy, indiscipline in work and management of the Pit Coal Company, to which are added more general causes such as the strategy to reduce emissions. carbon dioxide, lower economic efficiency of coal-based energy, the development of unconventional less polluting energy sources and why not and the detonation of the social 
bomb represented by the nearly 60,000 employees concentrated in a relatively small area such as the Jiu Valley.

A first ranking of the 10 mines in Jiu Valley remaining in operation in 2001, based on scientific criteria, was made in 2002 applying the technical and economic indicators achieved at the end of 2001.

Table 2 summarizes the hierarchy of the 10 mining operations in Jiu Valley, which operated at that time, ranking obtained according to the three evaluation criteria [3].

Table 2. Hierarchy of mines in the Jiu Valley according to evaluation criteria.

\begin{tabular}{|c|c|c|c|c|}
\hline \multirow{2}{*}{$\begin{array}{c}\text { No. } \\
\text { crt. }\end{array}$} & \multirow{2}{*}{ Mine } & \multicolumn{3}{|c|}{ Criteria for evaluating the conservation-closure } \\
\cline { 3 - 5 } & & Economic Class & Integrator Score & Points Score \\
\hline 1 & Valea de Brazi & V & 54 & 108.3 \\
\hline 2 & Uricani & III & 89 & 120.4 \\
\hline 3 & Bărbăteni & IV & 54 & 89.7 \\
\hline 4 & Lupeni & IV & 85 & 116.2 \\
\hline 5 & Paroșeni & IV & 64 & 95.5 \\
\hline 6 & Vulcan & IV & 73 & 103.4 \\
\hline 7 & Aninoasa & V & 45 & 56.9 \\
\hline 8 & Livezeni & IV & 82 & 101.0 \\
\hline 9 & Petrila & IV & 66 & 104.9 \\
\hline 10 & Lonea & III & 74 & 103.7 \\
\hline
\end{tabular}

It should be noted that the ranking of these mines was based on the detailed technical and economic indicators presented in work [3].

Analysing table 2 we find the following:

- According to the economic criterion, it appears that no mining unit in the Jiu Valley was, at that time, in classes I and II, most belonging to classes III (2), IV (6) and V (2), i.e. units with grade medium of attractiveness, low degree of attractiveness and respectively unattractive.

- According to the integrative criterion, considering the viability threshold of 58 points, corresponding to average values of the indicators evaluated, three mines Valea de Brazi, Bărbăteni and Aninoasa were below this threshold, being considered non-viable.

- According to the points criterion, three mines, Bărbăteni, Paroșeni and Aninoasa were located below the threshold of 100 .

Following these assessments, the decision was made to declare the Valea de Brazi, Bărbăteni and Aninoasa mines unviable and to enter the closure process. At the time of the cessation of state subsidies, in 2011, 7 mining operations were in operation in Jiu Valley: Lonea, Petrila, Livezeni, Vulcan, Paroșeni, Lupeni and Uricani.

Also now, a new evaluation will be made at the level of CNH-SA Petroșani from a technical, economic and social point of view to decide which of the seven mines will survive economically without social assistance.

Following such an analysis, two categories of units were established: non-viable (which must enter the closure process) and viable (those that will continue their activity).

The analysis was based on the projection of the following technical and economic indicators for the period 2011-2018:

1- exploitable coal reserves (share of exploitable coal reserves, energy content of reserves exploitable and the degree of assurance of the programmed pace of operation);

2 - efficiency of opening works (opening index), in $\mathrm{m} / 1000$ tons open reserve;

3 - efficiency of active mining works (extracted tons/m of active work);

4- the volume of open reserves and their share in total open reserves;

5 - the forecasted production level and energy content of coal;

6 - physical labor productivity; 
7- unit cost of production;

8 - the level of expenses per 1000 lei of goods production.

The scores obtained by the seven mining operations, analyzed and then in operation are shown in table 3 [3].

Table 3. Scores obtained from mines.

\begin{tabular}{|c|c|c|c|c|}
\hline No.crt. & Mine & Technical score & Economic score & TOTAL \\
\hline 1 & Lonea & 50.6 & 46.6 & 99.2 \\
\hline 2 & Petrila & 16.5 & 17.3 & 33.8 \\
\hline 3 & Livezeni & 55 & 53.8 & 108.8 \\
\hline 4 & Vulcan & 41.6 & 58.9 & 100.5 \\
\hline 5 & Paroșeni & 20.8 & 40.7 & 61.5 \\
\hline 6 & Lupeni & 49.1 & 49.8 & 98.9 \\
\hline 7 & Uricani & 21.4 & 22.8 & 44.2 \\
\hline
\end{tabular}

It is observed that the Petrila, Paroșeni and Uricani mines (marked in red), obtained the most low scores and were declared unviable, entering the closing process (2011-2017).

In 2012, the Jiu Valley National Mine Closure Company (SNIMVJ) was established, which took over all the mines in different stages of cessation of activities (conservationclosure).

Between 2011 and 2015 there were four viable mines in Jiu Valley: Lonea, Livezeni, Vulcan and Lupeni. The analysis of viable mines stopped until the end of 2015, when based on Feasibility Studies, developed by the University of Petroșani (for the Lonea mine) and S.C. Universal Cerc Proiect SRL (for the Livezeni, Vulcan and Lupeni mines), solutions were presented to continue the activities at these mines, with the acceptance of appropriate investments.

Following these studies, but also due to their uncertain state from 2016-2017, as CEHHunedoara (CEH-SA Petroșani) enters or leaves insolvency, the Romanian Government adopted (November 2016) a memorandum on increasing aid state granted to the National Society of Mine Closures Jiu Valley (SNIMVJ), with 129.129 million lei (approx. 28.7 million euros), for the inclusion in the closure program (until the end of 2018), of two mines, which were considered non-viable: Lonea and Lupeni [3].

So, at present, there are only two viable mines in Jiu Valley: Livezeni and Vulcan.

\section{Implementation of the strategy}

To analyze whether the proposed strategy is starting to come to life, in table 4 they were put objectives, measures and actions versus their achievements to date.

Table 4. Analysis of the implementation of the Strategy.

\begin{tabular}{|c|c|c|}
\hline Objectives & Measures and actions & Achievements \\
\hline \multirow{7}{*}{$\begin{array}{l}\text { Repositioning } \\
\text { the mining field } \\
\text { in the } \\
\text { perspective of } \\
\text { ensuring the } \\
\text { mineral } \\
\text { resources } \\
\text { necessary for } \\
\text { the sustainable } \\
\text { development of }\end{array}$} & redefining and updating the mineral resource base; & PARTIAL \\
\hline & increasing the country's budget revenue base; & NOT \\
\hline & creating new jobs and increasing the number of employees; & NOT \\
\hline & $\begin{array}{l}\text { development of geographical areas carrying mineral } \\
\text { resources with limited economic alternatives; }\end{array}$ & NOT \\
\hline & $\begin{array}{l}\text { changing the institutional framework in the field by } \\
\text { reorganizing some agencies and services; }\end{array}$ & NOT \\
\hline & $\begin{array}{l}\text { correlating the legislative framework in the field of mining } \\
\text { with domestic and European legislation; }\end{array}$ & PARTIAL \\
\hline & stimulating research, development, innovation; & NOT \\
\hline
\end{tabular}




\begin{tabular}{|c|c|c|}
\hline Objectives & Measures and actions & Achievements \\
\hline \multirow{3}{*}{$\begin{array}{l}\text { the country, } \\
\text { with priority } \\
\text { from domestic } \\
\text { production }\end{array}$} & $\begin{array}{l}\text { ensuring transparency and access to data in the field of } \\
\text { mineral resources; }\end{array}$ & NOT \\
\hline & increasing resource efficiency; & NOT \\
\hline & $\begin{array}{l}\text { framework conditions for research - innovation for } \\
\text { competition and development. }\end{array}$ & NOT \\
\hline \multirow{3}{*}{$\begin{array}{l}\text { Harmonization } \\
\text { of the national } \\
\text { interest of } \\
\text { increasing the } \\
\text { activities of the } \\
\text { mining sector } \\
\text { with the } \\
\text { requirements of } \\
\text { sustainable } \\
\text { development; }\end{array}$} & $\begin{array}{l}\text { improving the regulatory framework to ensure } \\
\text { predictability and fiscal stability for attracting new } \\
\text { investors by creating the investor's operational manual in } \\
\text { the field of mineral resources; }\end{array}$ & NOT \\
\hline & $\begin{array}{l}\text { creating the regulatory framework for public-private } \\
\text { partnership for mining activities by amending and } \\
\text { supplementing the Law on Public-Private Partnership; }\end{array}$ & NOT \\
\hline & $\begin{array}{l}\text { addressing sustainable mining on free market principles } \\
\text { through analysis in order to deregulate prices for mining } \\
\text { products in accordance with European legislation. }\end{array}$ & NOT \\
\hline \multirow{14}{*}{$\begin{array}{l}\text { Sustainable use } \\
\text { of the country's } \\
\text { mineral } \\
\text { resources in } \\
\text { harmony with } \\
\text { the } \\
\text { environment, } \\
\text { protection of } \\
\text { natural and } \\
\text { cultural } \\
\text { objectives in } \\
\text { the European } \\
\text { context; }\end{array}$} & $\begin{array}{l}\text { achieving environmental protection through biodiversity } \\
\text { conservation measures, air quality monitoring and } \\
\text { decontamination of historically polluted mining sites; }\end{array}$ & PARTIAL \\
\hline & sustainable development of mining communities; & NOT \\
\hline & $\begin{array}{l}\text { providing financial resources and guarantees for the } \\
\text { restoration and rehabilitation of the post-exploitation } \\
\text { environment; }\end{array}$ & PARTIAL \\
\hline & $\begin{array}{l}\text { the closure of mines in accordance with international best } \\
\text { practices and the management of green land; }\end{array}$ & NOT \\
\hline & $\begin{array}{l}\text { ensuring the socio-economic regeneration of the affected } \\
\text { communities following the mine closure process; }\end{array}$ & NOT \\
\hline & risk management and adaptation to climate change; & NOT \\
\hline & $\begin{array}{l}\text { improving dialogue and relations with other industries } \\
\text { through consultation between the various stakeholders and } \\
\text { the mining industry during the licensing process; }\end{array}$ & - \\
\hline & $\begin{array}{l}\text { harmonization of mining areas with natural and cultural } \\
\text { environments. }\end{array}$ & NOT \\
\hline & $\begin{array}{l}\text { integration of the package of information and regulations in } \\
\text { the field of mineral resources in the participatory strategic } \\
\text { planning for local and regional socio-economic } \\
\text { development; }\end{array}$ & NOT \\
\hline & $\begin{array}{l}\text { creation of a network for information transfer and exchange } \\
\text { of experience between similar structures in the country and } \\
\text { abroad; }\end{array}$ & NOT \\
\hline & promoting societal development and regional growth; & NOT \\
\hline & $\begin{array}{l}\text { cooperation between government institutions, academia and } \\
\text { research, professional, trade union, employers' } \\
\text { organizations, NGOs and the business community by } \\
\text { including all institutions and organizations interested in } \\
\text { finding new technologies in the field or in drafting new } \\
\text { legislative documents; }\end{array}$ & NOT \\
\hline & $\begin{array}{l}\text { the establishment of a National Advisory Council, a body } \\
\text { with an advisory role to monitor the implementation of the } \\
\text { provisions of the Mining Strategy; }\end{array}$ & NOT \\
\hline & $\begin{array}{l}\text { transposition into the Mining Law of the provisions of } \\
\text { Directive 2013/34 / EU on transparency rules for the } \\
\text { mining sector }\end{array}$ & NOT \\
\hline
\end{tabular}

Based on this Strategy, the following public policies had to be developed, approved by the government: 
- the socio-economic reconstruction of the localities in the areas most affected by the mining restructuring in order to transform them into development poles and implicitly for job creation for the adjacent areas as well;

- capitalization of coal resources from the Jiu Valley mining basin.

It is found, after 4 years from the launch of this Strategy, that almost all the objectives/measures/actions have not started and from the analysis of the realities on the ground there are no intentions to materialize them.

In the title of the article we asked ourselves: is the implementation of the Strategy a failure or an abandonment?

We believe that both attributes are to blame.

Arguments for failure can be supported by the following:

- under Article 194 (paragraph 2) TFEU (Treaty on the Functioning of the European Union) each Member State reserves the right to determine the conditions of exploitation of its energy resources, to choose between different energy sources and to establish the general structure of its energy supply [4];

- under the regulation, EU Member States must establish ten-year integrated national energy and climate plans (NECPs) for the period 2021-2030, report every two years on progress and develop coherent national long-term strategies. long to meet the objectives of the Paris Agreement [5];

- Parliament emphasized the need to make joint efforts in the field of new energy technologies for both renewable energy and sustainable fossil fuel technologies, as well as to provide additional public and private funding for successful implementation of the plan;

- currently, the Hunedoara Energy Complex is in insolvency, and Mintia Thermal Power Plant has been shut down since mid-March due to lack of coal;

- the production of the four mines in Jiu Valley (two of which are in the process of closing) is very low, and because of this coal-fired energy was traded at record prices, the complex did not sell any megawatts;

- 1488 employees of the Hunedoara Energy Complex (883 on the mining side and 605 on the Mintia Thermal Power Plant) opted for the collective dismissal, and they will receive an individual compensation of 10,000 euros. In addition, there will be a four-year period of social assistance paid by the state for miners and two years for energy workers [6];

- the total lack of interest of all those interested in the well-being of the area, with multiplier negative effects, in (re) defining the Jiu Valley as an attractive area, not for investments, but for daily living, as a place where you want to be [7];

- the mining unions in the Jiu Valley became the most important partners of the political forces that supported the slow reform of the socialist economy. And in recognition of this support, the beginning of the reform was made by raising wages, reducing the working week to five days, by six hours a day, and a fall in coal production by almost $50 \%$ in 1990 . This political decision not only delayed the restructuring of the mining sector, but increased the economic and social costs of the process that really started with the 1997 [7], wave of layoffs;

- inability to identify and promote alternatives for economic development to replace mining. Real alternatives, not imaginary solutions such as wishful thinking, such as the idea that tourism could compensate for the closure of mines, an idea mentioned in almost all interviews, discussions and local and national documents on the development strategy of the area;

- in order to correctly understand the current situation of the Jiu Valley, it is important to remember how the Communist Party's policy of ensuring the country's energy autonomy was implemented in the area in the 1970s: not through investment and technological modernization, but by bringing a large number of employees from other regions. Between 1966 and 1992, the stable population of Jiu Valley increased from 117,495 people to 
$167,456(+43 \%)$. After the first wave of restructuring and mass layoffs in 1997, in the early 2000 s, about $40 \%$ of the population of Jiu Valley remained made up of people who came to the Valley as a result of interregional labor migration;

- if the mining restructuring in Jiu Valley is a failure [7], the sources of failure lie, unfortunately, only partially in indifference, incompetence, corruption or inadequacy of the political decision. Some of the causes are structural, and others are related to the secondary but lasting and unpredictable consequences of mining.

As far as mining is concerned, a perverse, long-lasting and impactful effect on the (non) development of the region has been the labeling of miners as a professional category always willing to violate the rules and laws of the rule of law, and the Jiu Valley as a risky area, if not downright dangerous. Or, investments are attracted by stability and predictability, the inherent risk associated with opening any new business being balanced by the requirement and expectation of an environment, economic and social, stable and predictable. Uncertainty is acceptable in conditions of very high profit rates, obtained in a short time. Such conditions are characteristic of speculative behavior, not investment, and speculation has little or no influence on the economic development of the area in which they are made. And that is why, perhaps, the companies registered in the Jiu Valley as a result of its declaration as a disadvantaged area have chosen to benefit from the tax advantages granted by law, without the responsibility to create jobs and without producing a real improvement of the socio-economic climate. from the area.

Arguments for abandonment can be justified by the following:

- one of the five main objectives of EU energy policy is [5] to decarbonize the economy and the transition to a low-carbon economy, in accordance with the Paris Agreement: reducing emissions by at least 40\% compared to 1990 levels, an increase of $32 \%$ in the share of renewable energies in energy consumption;

- on 8 October 2020, the European Parliament voted to start negotiations with the Council of Europe with a global goal of reducing greenhouse gas emissions by $60 \%$ by 2030 and phasing out all direct and indirect subsidies for fossil fuels by late in 2025 [6];

- closure of mines was not an end in itself, but part of a "restructuring of Jiu Valley economy by replacing its dependence on the mining industry with a diverse range of sectors of activity, business and qualifications" (GD 646/2002). From this perspective, success fades significantly. Mining remained, at least until the middle of the first decade of the 2000 s, the main provider of prosperity in the area, those employed in the mining sector having a higher standard of living than those with other occupations [7]. Successful entrepreneurs were, then as now, interested in leaving Jiu Valley, while the others, most of them, carry out a subsistence entrepreneurship: they started a business and run it primarily to ensure their income to cover daily expenses. As a result, the private sector has not even managed to come close to taking on the role of engine of development in the area;

- why coal should be abandoned: coal electricity production is subject to harsh environmental regulations. For each MW produced there is an obligation to purchase 0.91 $\mathrm{CO}_{2}$ certificates $\left(0.91 \mathrm{t} \mathrm{CO}_{2}\right.$ is released into the atmosphere). The price of a certificate is almost 40 euros. That is, if it produces one MW, CEH must buy 36 euros (180 lei) of $\mathrm{CO}_{2}$ certificates. If the coal were of good quality, two tons are needed to produce one MW. On the international market, the price of coal is 54.5 euro/t. It turns out that for one MW produced, $\mathrm{CEH}$ spends 145 euro/MW only for coal and $\mathrm{CO}_{2}$ certificates, without labor and other expenses. The price of one MW on the OPCOM free market (next day market) has recently varied between 38 and 63 euro/MW. In any case, the production of electricity on coal is at a loss. The European Union, like Romania, wants the level of pollution to gradually decrease by 2050. (Green Deal plan which provides for the decarbonize of all industrial activities). Recently, vice-president of the European Commission, declared that Romania must give up coal [8]; 
- The Ministry of Energy postpones solving the problems for three months. It has not taken any action, it has not undertaken a national coal removal program.

\section{Conclusions}

To cope with globalization and climate change, governments' energy policy and integrated mining policy are vital strategic elements.

Romania, rich in poor deposits, with millennial experience in mining, is going through a critical period because after 1989, in addition to objective arguments regarding its restructuring, there were wrong decisions taken by both governments that alternated with the country's leadership, but it must we say it, and a indifference on the part of the mining guild which has not proved capable of opposing disastrous measures to the development of mining activities on the territory of the country.

In the last 31 years, the mining activity in Jiu Valley has been in a permanent process of restructuring and reorganization, with tens of thousands of people laid off, with substantial subsidies to mining, with billions of euros in debt, with failed development strategies, with newly established companies to increase the profitability of the mines which later proved to be just as damaging as the previous ones.

We are 4 years after the elaboration of the Mining Strategy of Romania and we find that it has not yet come to life: the mines are still closing, the greening of post-closure areas is difficult or not at all, coal imports for thermal power plants are increasing, known reserves of secondary resources (dumps, ponds) and examples can continue.

\section{References}

1. OM nr. 656/ 22.06.2016, Romania's Mining Strategy 2017 - 2035 (Romanian language), (2016)

2. C.G. Păcuraru, Hunedoara Energy Complex - untreated metastasis (Romanian language) [Online]. Available: https://www.contributors.ro/complexul-eenergetichunedoara-metastaza-netrata/. [Accessed 06 May 2021]

3. E. Cozma, Techniques and technologies of mining closing (Romanian language) (FOCUS Publishing House, Petroșani, 2006)

4. EU-Directive 2009/C 27/19, Opinion of the European Economic and Social Committee on the non-energy mining industry in Europe (2008)

5. EU-Directive 328/82, Renewable Energy Directive (2018)

6. This mix should be restructured (Romanian language), Minerit, [Online]. Available: https://cronicavj.ro/wp/?p=109793. [Accessed 06 June 2021]

7. D. Chiribucă, About mining, Jiu Valley and the announced failure of a delayed restructuring (Romanian language) [Online]. Available: https://www.revistasinteza.ro/despre-minerit-valea-jiului-si-esecul-anuntat-al-uneirestructurari-amanate. [Accessed 06 May 2021]

8. MEPs set ambitious targets for cleaner, more efficient energy use, [Online]. Available: http://www.europarl.europa.eu/news/en/press-room/20180112IPR91629. [Accessed 06 May 2021]

9. D. Fodor, Brief analysis of Romanian mining (Romanian language) Mining Revue, [Online]. Available: https://issuu.com/revmin/docs/nr4en2016 (2016) [Accessed 06 May 2021]

10. D. Fodor, M. Georgescu, Mining rescue solutions from Jiu Valley, Mining Revue no.4 (2016) [Online]. Available: https://issuu.com/revmin/docs/nr4en2016 [Accessed 06 May 2021] 